\title{
POLITIES
}

\section{Could This Supreme Court Case Affect Robert Mueller?}

An upcoming case might show how the justices would react to the special counsel being dismissed.

PETER M. SHANE APR 23, 2018

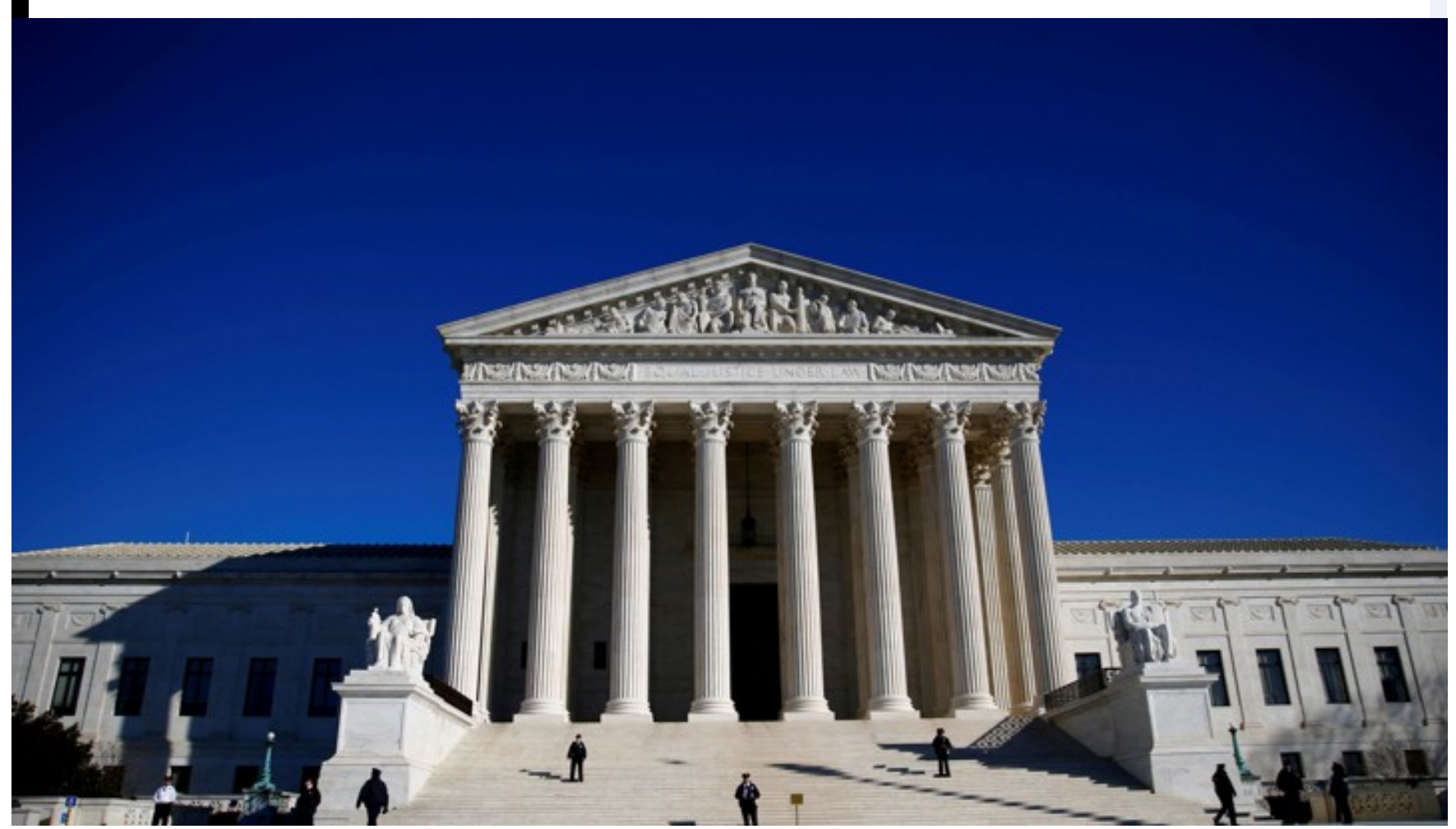

ERIC THAYER / REUTERS

An upcoming Supreme Court decision in a case most Americans have never heard of, and even lawyers will find obscure, could offer a clue about how the justices would react to President Trump firing Special Counsel Robert Mueller.

Technically, the case of Raymond J. Lucia v. Securities and Exchange Commission, being argued Monday, involves only the arcane question of whether SEC Administrative Law Judges are "officers" or "employees" of the United States. The Trump Administration's handling of the case reveals it, however, to be the latest chapter in a right-wing campaign to weaken independent administrators and to enlarge the power of presidents to bend the bureaucracy to their will. It may be one of the Court's most important decisions for the future of the rule of law. 
Raymond J. Lucia and his company allegedly defrauded investors at seminars touting a so-called "Buckets of Money" retirement wealth-management strategy. According to the Securities and Exchange Commission, Lucia falsely claimed to have proof that investors who followed the "Buckets of Money" approach would have weathered dramatic market downturns in earlier decades. Although the sanctions imposed on Lucia came from the SEC, its proceedings started with an Administrative Law Judge, or ALJ, who heard testimony, took evidence, and made several preliminary decisions that the Commission ultimately reviewed.

Here's the arcane part: Instead of appointing Administrative Law Judges, the SEC delegated that power to its chief administrative law judge. In Lucia's case, as in others, the chief ALJ selected an ALJ whom the federal Office of Personnel Management had properly found to be qualified for that role. Lucia argued unsuccessfully to the U.S. Court of Appeals for the D.C. Circuit that this selection was unconstitutional. He asserted that, under Article II of the Constitution, the ALJ had to be considered an "Officer of the United States." As such, she could properly be appointed only by the president or by the Securities and Exchange Commission. The chief ALJ could appoint another ALJ only if the appointed ALJ were a mere "employee," not an "officer." The Supreme Court agreed to take the question under review.

This appointments issue has no direct implications for Mueller. As the head of a department, Acting Attorney General Rod Rosenstein, who appointed the special counsel, is constitutionally qualified to make both officer and employee appointments. Yet the Court's handling of the appointments question will have enormous implications for administrative justice in the United States. As pointed out in an amicus brief "for neither party" by administrative law scholars, Congress created the ALJ system in the 1940s to help with the multifarious oral evidentiary hearings that are common throughout the federal government. Most ALJs, 1,655 out of 1,926, provide hearings regarding claims before the Social Security Administration. The system was intended to respond to complaints that federal hearing officers were too biased in favor of the agencies they worked for. By giving administrative adjudicators a measure of independence, Congress-and the Securities and Exchange Commission-were trying to give private parties like Lucia more a fair shake when their cases came before the government. 
Far from being hurt by the system, Lucia, if anything, was helped by it. If Lucia wins his case on the Appointments Clause issue, it could wreak havoc with the varied universe of federal programs of administrative adjudication, replacing merit-system appointments with a system more easily politicized. I am among a group of constitutional and administrative law scholars who have filed another amicus brief opposed on historical grounds to this outcome.

The deeper threat to the rule of law, however, comes not from the issue of appointments, but from another issue that the Court initially seemed to dodgenamely, whether administrative law judges must be dischargeable at will or whether, as is now the case, they may be fired only for "good cause." And make no mistake, the ultimate target here is not just administrative law judges, but all federal administrators who are "officers of the United States," including-perhaps especially-independent prosecutors like Mueller.

The Trump Administrator's eagerness to pursue the removal issue could not be more palpable. First, the current solicitor general, Noel Francisco, reversed the position of the Obama Administration, which had defended the Securities and Exchange Commission, and put the government instead on Lucia's side. Then, contrary to Lucia's lawyers, who have explicitly argued that the removal question is not properly presented, Francisco urged the Court to address the removal question. When the Court declined to include the removal issue in its grant of certiorari, Francisco went ahead and briefed it anyway, urging that ALJ's must be dischargeable for any "failure to perform adequately or to follow agency policies, procedures, or instructions." The Supreme Court has now granted him permission to share in the oral argument on behalf of Lucia, even though among the reasons Francisco gave for sharing the podium is precisely that "only the government has addressed in its brief the merits of the removal question." In a normal case, that would be a very strong reason for the Court not to take up the issue.

The solicitor general's breach of norms is best seen as the latest official salvo in the battle for unitary-executive theory, a constitutional view embraced by the Federalist Society since its founding in the 1980s. Adherents to this theory believe that the Constitution guarantees the president complete authority over how officials within the executive branch exercise all the administrative discretion Congress has vested in them. This implies, in their view, a presidential entitlement to remove all such officials at will-or at least for "failure ... to follow ... 
instructions." They believe the Supreme Court was wrong in 1935 to uphold Congress's power to insulate members of the Federal Trade Commission from atwill discharge. They believe the Court was wrong in 1988, when it upheld Congress's power to similarly protect independent counsels.

And they are chomping at the bit to put this theory into action. In 2011, U.S. Court of Appeals Judge Brett Kavanaugh, a Federalist Society stalwart, wrote a concurrence that, despite his disclaimer, was all but a brief for overturning the Supreme Court's 1935 precedent. His opinion was gratuitous advocacy in a case that did not require calling the Supreme Court's earlier decisions into question, a performance he all but repeated just last year. (Judge Kavanaugh's zeal may seem ironic given that his first claim to fame was as associate counsel to the independent counsel Kenneth W. Starr, whose remit to pursue President Bill Clinton Kavanaugh presumably now thinks was unconstitutional.)

But as the solicitor general's current conduct illustrates, neither lawyerly nor judicial norms may deter champions of unitary-executive theory from trying to goad the Supreme Court into whittling away at administrative independence from the president. A Supreme Court majority could oblige. They may well be unwilling to strip adjudicators like ALJ's of all removal protection. But the way they write an opinion could affect public perception surrounding the legitimacy of a potential Mueller dismissal. The Court might suggest without deciding, for example, that there is a genuine and unresolved issue whether presidents are entitled to fire all "Officers of the United States" who are not adjudicators like the ALJ's. Yet five votes even hinting that the constitutional status of an officer in Mueller's position is in question will embolden President Trump and his most constitutionally aggressive advisers. They will baselessly assert that the Court's handling of the issue-even if not addressing, much less resolving the question-implies that a Court majority might uphold a direct presidential dismissal of the special counsel.

The alternative to a "unitary-executive" presidency is a "checks-and-balances" presidency, in which it is most often up to Congress and to the departments of government that Congress created whether and how to balance the values of independent judgment and politically insulated accountability to the rule of law against the value of political accountability to the president. A case like Lucia, which implicates the evenhandedness of administrative judges, presents the least appealing context for expanding the president's capacity to make political 
appointments. But equally, America's Trumpian moment marks the least enticing time to certify a president's supposed constitutional authority to fire officials at will. Don't let the technical details fool you. A lot is at stake in Lucia.

We want to hear what you think about this article. Submit a letter to the editor or write toletters@theatlantic.com. 
